\title{
Compiling estimates of state pension obligations for the National Accounts (a methodology article)
}

\author{
Sarah Levy, Pensions Analysis Unit, Office for National Statistics (ONS)
}

\section{Introduction}

ONS is working to produce the first official estimate of the total obligations, or gross liabilities, of UK pension schemes. The work began in 2009 as part of efforts to address new international requirements for the National Accounts. These include a 'supplementary table' on pensions which all countries will have to include in their National Accounts.

The UK's first supplementary table on pensions will be produced on an experimental basis for the year 2010. The table will include estimates for unfunded pensions, which comprise public sector employee pensions and state pensions. For such pensions there is no pension fund: the payments are financed from taxation and employee contributions.

The first article in this series, which was published in August $2011^{1}$, provided an overview of the work in the context of the 2010 revision of the European System of Accounts (ESA), which is the EU-specific interpretation of the internationally agreed System of National Accounts. ESA2010 involves changes in the treatment of pensions, in particular the introduction of a 'supplementary table on pension schemes in social insurance' (see Table 1).

The first article also described the methodology that ONS - with the support of the Government Actuary's Department (GAD) - has developed for estimating the accrued-to-date obligations of public sector employee pension schemes. This article describes the methodology for producing similar estimates for state pensions, which will appear in Column $\mathrm{H}$ of the supplementary table on pensions. In the supplementary table, as elsewhere in the National Accounts, 'social security pension schemes in social insurance' do not include social assistance (income-related benefits). UK state pension estimates are for the contributory state pension, which is made up of the basic and additional state pensions. Pension Credit (a means-tested benefit for pensioners) and other non-contributory state pensions are not included ${ }^{2}$. The estimates have been produced for ONS by the Department for Work and Pensions (DWP). ONS and GAD have quality assured the results.

It should be noted that state pension liabilities are not liabilities in the sense of debt, because it is possible to change the obligations outstanding by enacting legislation or, if legislation is not required, by announcing changes to the rules. Such changes may affect service already accrued by pension scheme members, as in the case of the change in the basis of uprating for state pensions in payment discussed in Section 2. For this reason, pension liabilities are properly defined as 'contingent pension obligations' rather than debt in the Maastricht sense. Contingent pension obligations are not the same as 'contingent liabilities' as defined by HM Treasury for the purposes of the Whole of Government Accounts and by the Office for Budget Responsibility in its fiscal sustainability reports ${ }^{3}$.

\footnotetext{
${ }^{1}$ Levy, S. (2011), see Sources and further reading.

2 Pension Credit is the main non-contributory state pension. There are two small non-contributory elements of the Basic State Pension: Category C, which is is payable to people over State Pension Age on 5 July 1948 and their widows; and Category D, which is paid to people aged 80 and over in certain circumstances (see Pension Trends Chapter 5: State pensions in Sources and further reading).
}

3 HM Treasury (2011) and Office for Budget Responsibility (2011), published on 13 July 2011 (see Sources and further reading). These reports define 'contingent liabilities' as liabilities which are associated with events which may arise in future but are improbable (less than 50 per cent probability); some of these events are also unquantifiable. 
Table 1: Supplementary table on pension schemes in social insurance

\begin{tabular}{|c|c|c|c|c|c|c|c|c|c|c|c|c|}
\hline \multirow{5}{*}{$\begin{array}{l}\text { Rela- } \\
\text { tions }\end{array}$} & \multirow{5}{*}{$\begin{array}{l}\text { Row } \\
\text { No. }\end{array}$} & \multirow{5}{*}{$\begin{array}{r}\text { Recording } \\
\text { Pension manager } \\
\\
\text { Column number }\end{array}$} & \multicolumn{6}{|c|}{ Core national accounts } & \multicolumn{2}{|c|}{$\begin{array}{c}\text { Not in the core } \\
\text { national accounts }\end{array}$} & \multirow{4}{*}{$\begin{array}{l}\text { Total } \\
\text { pension } \\
\text { schemes }\end{array}$} & \multirow{4}{*}{$\begin{array}{c}\text { Counter- } \\
\text { parts: } \\
\text { Pension } \\
\text { entitle- } \\
\text { ments of } \\
\text { non- } \\
\text { resident } \\
\text { house- } \\
\text { holds }\end{array}$} \\
\hline & & & \multirow[b]{3}{*}{$\begin{array}{l}\text { Defined } \\
\text { con- } \\
\text { tribution } \\
\text { schemes }\end{array}$} & \multirow{3}{*}{$\begin{array}{c}\text { eral govern } \\
\text { Defined } \\
\text { benefit } \\
\text { schemes } \\
\text { and } \\
\text { other }{ }^{1)} \\
\text { non- } \\
\text { defined } \\
\text { contri- } \\
\text { bution } \\
\text { schemes }\end{array}$} & \multirow[b]{3}{*}{ Total } & \multicolumn{5}{|c|}{ General government } & & \\
\hline & & & & & & & $\begin{array}{r}\text { Define } \\
\text { general g }\end{array}$ & $\begin{array}{l}\text { Denefit sch } \\
\text { eernment } \mathrm{e}\end{array}$ & $\begin{array}{l}\text { mes for } \\
\text { ployees }\end{array}$ & \multirow[b]{2}{*}{$\begin{array}{l}\text { Social } \\
\text { security } \\
\text { pension } \\
\text { schemes }\end{array}$} & & \\
\hline & & & & & & $\begin{array}{l}\text { Defined } \\
\text { contri- } \\
\text { bution } \\
\text { schemes }\end{array}$ & $\begin{array}{l}\text { Classi- } \\
\text { fied in } \\
\text { financial } \\
\text { corpora- } \\
\text { tions }\end{array}$ & $\begin{array}{l}\text { Classi- } \\
\text { fied in } \\
\text { general } \\
\text { govt }^{31}\end{array}$ & $\begin{array}{l}\text { Classi- } \\
\text { fied in } \\
\text { general } \\
\text { govern- } \\
\text { ment }\end{array}$ & & & \\
\hline & & & A & B & $\mathrm{C}$ & $\mathrm{D}$ & $E$ & $\mathrm{~F}$ & G & $\mathrm{H}$ & $\mathrm{I}$ & $\mathrm{J}$ \\
\hline & & \multicolumn{11}{|c|}{ Opening balance sheet } \\
\hline & 1 & Pension entitlements & & & & & & & & & & \\
\hline & & \multicolumn{11}{|c|}{ Changes in pension entitlements due to transactions } \\
\hline $\begin{array}{l}\sum 2.1 \\
\text { to } 2.4\end{array}$ & 2 & $\begin{array}{l}\text { Increase in pension } \\
\text { entitlements due to } \\
\text { social contributions }\end{array}$ & & & & & & & & & & \\
\hline & 2.1 & $\begin{array}{l}\text { Employer actual } \\
\text { social contributions }\end{array}$ & & & & & & & & & & \\
\hline & 2.2 & $\begin{array}{l}\text { Employer imputed } \\
\text { social contributions }\end{array}$ & & & & & & & & & & \\
\hline & 2.3 & $\begin{array}{l}\text { Household actual } \\
\text { social contributions }\end{array}$ & & & & & & & & & & \\
\hline & 2.4 & $\begin{array}{l}\text { Household social } \\
\text { contribution } \\
\text { supplements }^{5)}\end{array}$ & & & & & & & & & & \\
\hline & 3 & $\begin{array}{l}\text { Other (actuarial) } \\
\text { change of pension } \\
\text { entitlements in social } \\
\text { security pension } \\
\text { schemes }\end{array}$ & & & & & & & & & & \\
\hline & 4 & $\begin{array}{l}\text { Reduction in pension } \\
\text { entitlements due to } \\
\text { payment of pension } \\
\text { benefits }\end{array}$ & & & & & & & & & & \\
\hline \multirow[t]{7}{*}{$\begin{array}{l}2+3 \\
-4\end{array}$} & 5 & $\begin{array}{l}\text { Changes in pension } \\
\text { entitlements due to } \\
\text { social contributions } \\
\text { and pension benefits }\end{array}$ & & & & & & & & & & \\
\hline & 6 & $\begin{array}{l}\text { Transfers of pension } \\
\text { entitlements between } \\
\text { schemes }\end{array}$ & & & & & & & & & & \\
\hline & 7 & $\begin{array}{l}\text { Changes in pension } \\
\text { entitlements due to } \\
\text { pension scheme } \\
\text { reforms }\end{array}$ & & & & & & & & & & \\
\hline & & \multicolumn{11}{|c|}{ Changes in pension entitlements due to other flows } \\
\hline & 8 & $\begin{array}{l}\text { Changes in } \\
\text { entitlements due to } \\
\text { revaluations }\end{array}$ & & & & & & & & & & \\
\hline & 9 & $\begin{array}{l}\text { Changes in } \\
\text { entitlements due to } \\
\text { other changes in } \\
\text { volume }\end{array}$ & & & & & & & & & & \\
\hline & & \multicolumn{11}{|c|}{ Closing balance sheet } \\
\hline \multirow[t]{3}{*}{$\begin{array}{l}1+\Sigma \\
5 \text { to } 9 \\
\end{array}$} & 10 & Pension entitlements & & & & & & & & & & \\
\hline & & \multicolumn{11}{|c|}{ Related indicators } \\
\hline & 11 & Output & & & & & & & & & & \\
\hline
\end{tabular}

1) Such other non-defined contribution schemes, often described as hybrid schemes, have both a defined benefit and a defined contribution element.

2) Schemes organised by general government for its current and former employees.

3) These are non-autonomous defined benefit schemes whose pension entitlements are recorded in the core national accounts.

4) Counterpart data for non-resident households will only be shown separately when pension relationships with the rest of the world are significant.

5) These supplements represent the return on members' claims on pension schemes, both through investment income on defined contribution schemes' assets and for defined benefit schemes through the unwinding of the discount rate applied.

6) A more detailed split of these positions should be provided for columns $\mathrm{G}$ and $\mathrm{H}$ based on the model calculations carried out for these schemes.

The cells shown as are not applicable; the cells in will contain different data from the core national accounts. 


\section{Methodology}

This section describes the work that has been done by DWP, ONS and GAD to produce the state pension estimates for the 2010 experimental supplementary table.

The supplementary table is prepared on an 'accrued-to-date' basis, in line with similar information contained in the National Accounts. This means that Rows 1 and 10 (entitlements/ liabilities) show the amounts due for service to date (at the beginning and end of the year respectively). They do not include rights which will be built up in the future.

However, the work that is routinely carried out by DWP to forecast expenditure on state pensions takes into account future accumulation of pension rights, as well as rights accrued to date. This is because the purpose of such forecasts is to establish whether expenditure flows are sustainable as part of long term projections of government expenditure.

This section starts by discussing the models used by DWP to produce the estimates of state pension expenditure for the long term projections. It then explains the adjustments that had to be made in order to produce estimates for Rows 1 and 10 of the supplementary table (Column $\mathrm{H}$ ) on an 'accrued-to-date' basis. Additional adjustments due to the modelling assumptions required for the National Accounts are also explained. A discussion of the procedure for discounting expenditure flows to produce estimates of the present value of expenditure concludes the discussion of how the entitlements/liabilities were estimated.

\subsection{Modelling state pensions for the long term projections}

In the UK, the contributory state pension is made up of two tiers: the Basic State Pension (BSP), which provides a flat-rate pension in retirement, and the additional state pension ${ }^{4}$. In order to qualify for the full BSP, which was $£ 102.15$ per week for a single person in $2011 / 12$, people reaching State Pension Age (SPA) on or after 6 April 2010 need to have 30 'qualifying years' (reduced from 44 years for men and 39 years for women reaching SPA before this date). If they have fewer qualifying years, they receive a partial payment in proportion to the number of qualifying years they have built up. Qualifying years are built up by paying National Insurance (NI) contributions while working or, if not in work, through credits. People may also purchase qualifying years by making additional voluntary contributions.

With the additional state pension, employees (but not the self-employed) add to the BSP by making extra contributions in order to receive additional pension payments. People who care for others can build up entitlements through credits. The additional state pension was first introduced as the State Earnings-Related Pension Scheme (SERPS) in 1978. SERPS was replaced by the State Second Pension (S2P) in 2002. In DWP's modelling for the long term projections, references to Additional Pension (AP) refer to SERPS and S2P. Estimates for the state graduated retirement benefit scheme (GRAD), a forerunner of SERPS to which it was possible to contribute between 1961 and 1975, are produced separately (see below).

People can defer receipt of their state pension beyond SPA. In such cases, the initial entitlement is increased at a rate of 1 per cent for every five weeks of deferral or 10.4 per cent for a complete year. If people defer for 12 consecutive months or more, they can choose to receive a lump sum instead of the amount that they would have been paid as a pension. The lump sum is equivalent to the amount of deferred pension payments plus interest at 2 per cent above the Bank of England base rate.

\footnotetext{
${ }^{4}$ Further details are available in Pension Trends Chapter 5: State pensions (see Sources and further reading).
} 
DWP's long term projections of state pension expenditure are based on two models: the BSP model and the AP model, discussed below. The BSP model is also used to produce separate estimates for GRAD and for lump sums.

\subsubsection{The BSP model}

The BSP model is made up of two parts: the first comprises people who are currently over SPA, referred to in this article as 'pensioners'; the second comprises the 'inflows' of working age people into the pensioner population as they reach SPA. For each group, it is necessary to estimate expenditure on BSP from the date of the accounts (end-2009 or end-2010 in the case of the 2010 supplementary table) until the date at which the youngest person of working age (age 16) is expected to die.

For the first group (pensioners), the model takes information on initial amounts of BSP paid to pensioners at SPA from the Quarterly Statistical Enquiry (QSE), a biannual 5 per cent sample of administrative data. Over time, these initial amounts of BSP are adjusted for changes in pensioners' lives after SPA such as changes in marital status, including widowhood ${ }^{5}$; they are also increased each year in line with uprating policy (see Section 2.2.2). Pensioners remain in the population until death, which is estimated using mortality rates from the ONS's 2008-based national population projections. The mortality rates used in the model are split by sex and single year of age up to 125 years.

For the second group (working age people reaching SPA), it is necessary to estimate both the initial numbers of people (cohorts reaching SPA) and amounts of BSP that will be paid to them when they reach SPA. These 'inflows' into the pensioner population can then be treated in the same way as the estimates for existing pensioners, including adjusting for changes in their lives after SPA and increasing pensions in line with uprating policy.

In order to estimate inflows, the BSP model creates a 'caseload forecast' for each cohort of working age people reaching SPA until the youngest person (age 16 at the date of the accounts) reaches SPA. The caseload forecast is estimated by creating 17,550 groups, representing different combinations of: country of residence ${ }^{6}$, sex, marital status, age, personal entitlement to BSP as a percentage of full BSP, and category of pension (see Box 1). Some combinations are not possible in practice, so some groups have no one in them.

The number of people in each group is multiplied by the average BSP payment for that group at SPA (based on multiplying the personal entitlement to BSP for the group by the projected value of full BSP that year) to create an expenditure forecast for the group when it reaches SPA. This expenditure forecast can be treated in a similar way to the initial amounts of BSP paid to existing pensioners at SPA, as described above.

In order to allocate people to the right group in the caseload forecast, data on personal entitlements to BSP is needed. This comes from the 'L2 dataset' (a 1 per cent sample of HM Revenue and Customs' National Insurance Recording System). L2 shows the entitlement to BSP built up by each person in terms of qualifying years, whether as a result of paying $\mathrm{NI}$ contributions while working or as a result of building up credits or through payment of additional voluntary contributions. Age and sex data from the $L 2$ dataset is also used to show when people will reach SPA (which 'SPA cohort' they belong to).

\footnotetext{
${ }^{5}$ Further details of the BSP model including adjustments to deal with changes in pensioners' lives after SPA are available in the paper 'DWP Long Term Basic State Pension Modelling' (see Sources and further reading).

${ }^{6}$ Pensioners living overseas are entitled to receive BSP from the UK if they have built up qualifying years during their working lives, but their entitlement is treated differently depending on where they are resident (see Box 1).
} 
To forecast numbers reaching SPA in each year, the model uses ONS's 2008-based national population projections. These provide the total potential number of inflows, which are then split by level of personal entitlement on a cohort basis using information from the L2 dataset. The numbers from the L2 dataset are adjusted using information from the QSE, because the L2 data is known to underestimate future entitlements to BSP.

\section{Box 1: Categories used in the BSP caseload forecast}

\section{Country of residence ${ }^{1}$}

Sex

Marital status ${ }^{2}$

Age

Personal entitlement

Category of pension ${ }^{3}$
$\mathrm{GB}$, non-frozen rate overseas, frozen rate overseas.

Male, female.

Male, single female, married female, divorced female, widowed female.

60-125 (women), 65-125 (men).

Proportion of full BSP: 0\%, 0-50\%, 50-60\%, 60-80\%, 80-100\%, $100 \%$.

A: entitlement based on a person's own contributions.

B: entitlement based on partner's contribution record, paid when the person is not entitled to a Category A pension.

1 Pensions of people living overseas in countries with a non-frozen rate are uprated in the same way as those of people living in the UK, but those living in 'frozen rate' countries have their state pensions frozen at the rate they were first paid. A full list of frozen/non-frozen rate countries is available from http://research.dwp.gov.uk/asd/asd4/sp historical overseas expenditure.xls

2 Data on marital status is from ONS marital status projections (2006). This is an important factor when modelling the caseload forecast for women.

3 Note that 'category of pension' combined with 'marital status' and 'personal entitlement' information gives further breakdowns. Also, some people have both category A and B components. If someone has less than $60 \%$ of Category $A$, their pension can be topped up using their partner's contributions. There are a number of combinations, e.g. $A B, A B L$ and $B L$.

\section{Source: Department for Work and Pensions}

It should be noted that the model produces estimates for Great Britain (GB) in the first instance; these include payments to pensioners resident overseas who have rights to UK state pensions. Forecasts for numbers of overseas residents are currently produced by assuming that a proportion (for example 12 per cent of the 2009/10 'SPA cohort') of the total is overseas residents. DWP is working to improve this methodology. Forecasts for the UK are produced by uprating the GB (including overseas) estimates using a factor based on the ratio of pensioner numbers in Northern Ireland to those in $\mathrm{GB}^{7}$.

Although the model is based on the two parts discussed above - (i) current pensioners and (ii) inflows of working age people reaching SPA - it also needs to allow for inflows of people into the pensioner population after SPA (in cases where people decide to defer taking their state pensions beyond SPA) and associated payments of deferred pensions and lump sums. Inflows after SPA are derived using historic inflow numbers from the QSE combined with ONS population figures to predict how many people with unclaimed entitlement are above SPA at any point in time, and when they are likely to claim state pension. Some adjustments are made to allow for changes in the behaviour of women as women's SPA rises from April 2010.

To estimate the payments associated with inflows after SPA, the model uses data from the QSE on take-up rates for deferred pensions and lump sums combined with calculations of amounts payable

\footnotetext{
${ }^{7}$ As part of quality assurance, GAD pointed out that the use of this ratio produces a double allowance for pensioners overseas who originate from Northern Ireland because the GB figure includes residents overseas originating from all parts of the UK. The effect of this double counting was judged to be negligible, so no adjustment has been made for 2010 , but GAD has recommended making an adjustment in future years.
} 
based on the rules applying to each. Deferred pension payments are included in estimates of BSP in DWP's model, while results for lump sums are calculated separately (see Section 2.2.1).

Finally, the BSP model is used to produce estimates for GRAD, even though GRAD is a forerunner of the additional state pension. For current pensioners, administrative data from the QSE shows the proportion receiving GRAD at SPA. The proportion of future SPA cohorts with GRAD entitlement is calculated using information from the L2 database. From 2023/24 there are assumed to be no new cases reaching SPA because GRAD could no longer be accrued after 5 April 1975.

\subsubsection{The AP model}

The BSP model is a payouts-based model: it is based on estimates/forecasts of pension payments at SPA for current and future pensioners. By contrast, the AP model is an accruals-based model. Estimates of entitlement to SERPS and S2P accrued during people's working lives (revalued by earnings growth) are used to estimate their entitlements to AP from SPA.

After SPA, entitlements are adjusted for changes in pensioners' lives, such as widowhood. They are increased each year in line with inflation until death, which is estimated using mortality rates from the ONS's 2008-based national population projections.

In order to produce estimates/forecasts of entitlement to AP there are three stages. The first stage uses the L2 database to produce earnings factors ${ }^{8}$ based on:

- Numbers of jobs from DWP's cohort employment model,

- Numbers of people by individual age earning at each of three levels:

1. between the Lower Earnings Limit and the Lower Earnings Threshold

2. between the Lower and Upper Earnings Thresholds

3. between the Upper Earnings Threshold and the Upper Accrual Point

- Deductions for contracting out of AP into private pension schemes.

For the 2010 supplementary table, the earnings factors between 2008/09 and the date of the accounts (end-2009 or end-2010) had to be projected as 2008/09 was the last year of actual data available from the L2 database.

The second stage combines the earnings factors (whether from the L2 database or projected) with accrual rates. Accrual rates are defined in legislation and are used to turn earnings factors into accrued AP entitlements.

In the third stage, for each cohort of people, entitlements accrued in a particular financial year are increased until SPA according to the rules on revaluation during working life - currently in line with earnings growth (see Table 2). They are then converted into a 'gross AP entitlement' for the cohort at SPA and this is increased from SPA in line with inflation.

Thus, accrued AP entitlements =

- Earnings * rate of accrual... revalued in line with earnings growth until SPA

- Earnings * rate of accrual... uprated in line with inflation from SPA

Carer credits are modelled separately using data on benefit caseloads, economic activity, information from the L2 database and ONS population projections.

${ }^{8}$ For further details, see the paper 'DWP Earnings Factor Modelling: Turning earnings distributions into earnings factors' (Sources and further reading). 
Table 2: Earnings revaluation rates used in the AP model

\begin{tabular}{|l|r|}
\hline \multicolumn{1}{|c|}{ Financial year } & $\begin{array}{c}\text { Earnings } \\
\text { revaluation rate }\end{array}$ \\
\hline $2009 / 10$ & 1.031 \\
\hline $2010 / 11$ & 1.012 \\
\hline $2011 / 12$ & 1.009 \\
\hline $2012 / 13$ & 1.020 \\
\hline $2013 / 14$ & 1.022 \\
\hline $2014 / 15$ & 1.041 \\
\hline $2015 / 16$ & 1.044 \\
\hline $2016 / 17$ & 1.045 \\
\hline $2017 / 18$ & 1.048 \\
\hline
\end{tabular}

1 The 2017/18 assumptions are repeated for all future years.

2 Historical rates are based on the Average Earnings Index. Forecasts are consistent with the Budget 2011 economic assumptions up to 2016/17 and the Office for Budget Responsibility's long term economic assumptions as of July 2011 from 2017/18 onwards.

Source: Department for Work and Pensions

It should be noted that the AP model currently has some weaknesses, which DWP's forecasting team is working to resolve. These are:

- It only forecasts the amount of money going to a cohort of people based on total accruals in each year; it does not show the distribution between different groups. However, this does not affect the estimates produced for the National Accounts.

- It does not distinguish between GB and overseas cases, so all entitlements are uprated from SPA (even those in 'frozen rate' countries).

\subsection{Adapting to National Accounts requirements}

\subsubsection{Accrued-to-date estimates}

The main adjustment needed for the National Accounts supplementary table on pensions involved putting the estimates generated by the long term projections model onto an 'accrued-to-date' basis. This is because the long term projections model used by DWP to forecast expenditure on state pensions takes into account future accumulation of pension rights as well as rights accrued to date. However, the National Accounts shows accrued-to-date pension entitlements/liabilities.

Putting the estimates from DWP's models onto an 'accrued-to-date' basis meant removing any accruals beyond the date of the accounts (in the case of the 2010 supplementary table: end-2009 for Row 1 of the supplementary table and end-2010 for Row 10). For the AP model, this was relatively straightforward because it is an accruals-based model. This meant that accruals could be 'turned off' after the date of the accounts (for December 2009 taking three-quarters of accruals in 2009/10; and for December 2010 taking three-quarters of accruals in 2010/11).

For the BSP model the change to an 'accrued-to-date' basis was more complicated. In the BSP model's caseload forecast, the proportions of full BSP that people should receive based on their working lives and qualifying years had to be changed to estimate personal entitlement to 2009/10 and $2010 / 11^{9}$ rather than personal entitlement when they reached SPA ${ }^{10}$. Further adjustments were needed to ensure that the alignment of the L2 data with the QSE data (see Section 2.1.1) was not affected by this change.

\footnotetext{
${ }^{9}$ The long term projections model for BSP works on financial years; it was not possible to change it to calendar years.

${ }^{10}$ Although GRAD estimates are based on the BSP model, there was no need to turn off accruals for GRAD because accruals have already ceased.
} 
When modelling BSP on an accrued-to-date basis, a problem was encountered with 'inherited rights': the rights to BSP of people with Category B pensions (those based on a spouse or civil partner's contribution record, see Box 1). When DWP sought to run the long term projection model on an accrued-to-date basis, the model assumed that many people reaching SPA after the date of the accounts had only a partial state pension based on their own contributions (Category A) because qualifying years were only allowed for up to the date of the accounts. Thus the model automatically projected that they would receive inherited rights (Category $B$ ), as their pensions based on contributions paid to the date of the accounts were insufficient.

To avoid distorting the result, DWP and ONS agreed to remove all inherited rights for people reaching SPA after the date of the accounts. This was justified on the basis that the changes introduced from 6 April 2010 by the Pensions Act 2007 (see Box 2) should mean that in future most people will qualify for full BSP in their own right. However, GAD has pointed out that this is a considerable approximation, and has recommended further work in future to address the issue.

\section{Box 2: The Pensions Act 2007}

The Pensions Act 2007 introduced a package of measures including, from 6 April 2010:

- a reduction in the number of qualifying years for full BSP to 30 (from 44 for men and 39 for women) for those reaching SPA on or after this date,

- the ending of the requirements (a) for people to have at least one-quarter of the full number of qualifying years to receive any BSP and (b) for at least one year to come from paid contributions rather than credits, and

- the introduction of a new system of carer credits.

Source: Pension Trends Chapter 5: State pensions

A different approach was used for producing estimates of lump sums for the supplementary table because it proved difficult to forecast annual expenditure on lump sums on an accrued-to-date basis. Therefore, the forecast from the long term projections was adjusted using ratios. These ratios were calculated as: BSP expenditure on the accrued-to-date basis divided by BSP expenditure on the long term projections basis ${ }^{11}$. Separate ratios were produced for each year, by age and gender. They were applied to the forecast for lump sums from the long term projections, producing a downwards adjustment. Adjustments were also made to allow for the different assumptions on SPA used for the National Accounts work compared to those used for the long term projections (see Section 2.2.2).

\subsubsection{Changes in model assumptions}

Some modelling assumptions also had to be altered in order to meet the requirements for the National Accounts supplementary table on pensions. In particular, it was necessary that the estimates should be based on legislation already enacted at the date of the accounts, and that modelling assumptions should not include reforms enacted thereafter. This meant that SPA rules had to be based on the Pensions Act 1995 which raised SPA for women to 65 by 2020 and the Pensions Act 2007 which provided for a gradual increase in SPA for men and women to 68 by 2046. This meant changing the assumptions in DWP's long term projections model, which were based on the schedule of increases in SPA contained in the Pensions Bill 2011 as at July $2011^{12}$, although the Bill only became an Act of Parliament in November 2011.

\footnotetext{
${ }^{11} \mathrm{BSP}$ was used in preference to AP to derive the ratios, as most lump sum payments are related to BSP.

${ }^{12}$ At the time of the publication of the long term projections in Office for Budget Responsibility (2011).
} 
The 2011 supplementary table will incorporate the changes to SPA under the Pensions Act 2011, which provide for women's SPA to rise to 65 by November 2018 and for SPA for both sexes to rise to 66 by October 2020. A comparison of estimates in the 2011 supplementary table with those in the 2010 supplementary table will shed light on the impact of the increased pace of SPA changes.

Another change in modelling assumptions related to the uprating rules for BSP. DWP's long term projections model uses assumptions based on the 'triple lock' policy, which was introduced by an official announcement in the June 2010 Budget (no legislation was required). The triple lock policy stated that in future the BSP would increase each year by average earnings growth, inflation (using the CPI) or 2.5 per cent, whichever was higher. As this announcement was made during 2010 , the 2010 supplementary table required different uprating assumptions for the BSP estimates produced as at December 2009, before the triple lock was announced, and those produced as at December 2010, after its announcement (see Tables 3 and 4).

Similarly, there was an announcement in the June 2010 Budget that inflation uprating for state pensions would move from the Retail Prices Index (RPI) to the Consumer Prices Index (CPI). Therefore in the 2010 supplementary table, for uprating AP by inflation after SPA, it was necessary to use the RPI for the December 2009 estimates and the CPI for the December 2010 estimates.

Table 3: Economic assumptions used for the supplementary table in the calculation of the BSP model estimates for December 2009

\begin{tabular}{|c|c|c|l|l|}
\hline $\begin{array}{c}\text { Financial } \\
\text { year }\end{array}$ & $\begin{array}{c}\text { Calendar } \\
\text { year }\end{array}$ & $\begin{array}{c}\text { Uprating } \\
\text { value }\end{array}$ & \multicolumn{1}{|c|}{ Uprated by } & \multicolumn{1}{|c|}{ Policy } \\
\hline $2004 / 05$ & 2005 & 1.028 & RPI & RPI, $2.5 \%$ \\
\hline $2005 / 06$ & 2006 & 1.031 & RPI & RPI, $2.5 \%$ \\
\hline $2006 / 07$ & 2007 & 1.027 & RPI & RPI, $2.5 \%$ \\
\hline $2007 / 08$ & 2008 & 1.036 & RPI & RPI, $2.5 \%$ \\
\hline $2008 / 09$ & 2009 & 1.039 & RPI & RPI, $2.5 \%$ \\
\hline $2009 / 10$ & 2010 & 1.05 & RPI & RPI, $2.5 \%$ \\
\hline $2010 / 11$ & 2011 & 1.025 & $2.5 \%$ & RPI, $2.5 \%$ \\
\hline $2011 / 12$ & 2012 & 1.046 & RPI & RPI, $2.5 \%$ \\
\hline $2012 / 13$ & 2013 & 1.021 & Earnings & Earnings \\
\hline $2013 / 14$ & 2014 & 1.02 & Earnings & Earnings \\
\hline $2014 / 15$ & 2015 & 1.038 & Earnings & Earnings \\
\hline $2015 / 16$ & 2016 & 1.043 & Earnings & Earnings \\
\hline $2016 / 17$ & 2017 & 1.045 & Earnings & Earnings \\
\hline $2017 / 18$ & 2018 & 1.04754 & Earnings & Earnings \\
\hline
\end{tabular}

1 The 2017/18 assumptions are repeated for all future years.

2 Forecasts of inflation and earnings growth are consistent with the Budget 2011 economic assumptions up to 2016/17 and the Office for Budget Responsibility's long term economic assumptions as of July 2011 from 2017/18 onwards.

Source: Department for Work and Pensions 
Table 4: Economic assumptions used for the supplementary table in the calculation of the BSP model estimates for December 2010

\begin{tabular}{|c|c|c|l|l|}
\hline Financial year & Calendar year & $\begin{array}{c}\text { Uprating } \\
\text { value }\end{array}$ & \multicolumn{1}{|c|}{ Uprated by } & \multicolumn{1}{|c|}{ Policy } \\
\hline $2004 / 05$ & 2005 & 1.028 & RPI & RPI, $2.5 \%$ \\
\hline $2005 / 06$ & 2006 & 1.031 & RPI & RPI, $2.5 \%$ \\
\hline $2006 / 07$ & 2007 & 1.027 & RPI & RPI, $2.5 \%$ \\
\hline $2007 / 08$ & 2008 & 1.036 & RPI & RPI, $2.5 \%$ \\
\hline $2008 / 09$ & 2009 & 1.039 & RPI & RPI, $2.5 \%$ \\
\hline $2009 / 10$ & 2010 & 1.050 & RPI & RPI, $2.5 \%$ \\
\hline $2010 / 11$ & 2011 & 1.025 & $2.50 \%$ & RPI, $2.5 \%$ \\
\hline $2011 / 12$ & 2012 & 1.046 & RPI & RPI, CPI, earnings, $2.5 \%$ \\
\hline $2012 / 13$ & 2013 & 1.043 & CPI & CPI, earnings, $2.5 \%$ \\
\hline $2013 / 14$ & 2014 & 1.025 & $2.50 \%$ & CPI, earnings, $2.5 \%$ \\
\hline $2014 / 15$ & 2015 & 1.038 & Earnings & CPI, earnings, $2.5 \%$ \\
\hline $2015 / 16$ & 2016 & 1.043 & Earnings & CPI, earnings, $2.5 \%$ \\
\hline $2016 / 17$ & 2017 & 1.045 & Earnings & CPI, earnings, $2.5 \%$ \\
\hline $2017 / 18$ & 2018 & 1.0495 & Earnings plus $0.2 \%$ & \\
\hline
\end{tabular}

1 The 2017/18 assumptions are repeated for all future years.

2 Forecasts of inflation and earnings growth are consistent with the Budget 2011 economic assumptions up to 2016/17 and the Office for Budget Responsibility's long term economic assumptions as of July 2011 from $2017 / 18$ onwards.

3 The long term uprating assumption (from 2017/18) is earnings plus $0.2 \%$, in line with the triple lock policy. Historically, earnings have risen more rapidly than prices (or 2.5 per cent) in most years, so under the triple lock policy, BSP increases are expected to keep pace with earnings growth in future. However, in years when earnings growth is sluggish, BSP increases might outpace earnings increases, so $0.2 \%$ is added to the earnings growth forecast for the long term uprating assumption.

\section{Source: Department for Work and Pensions}

\subsection{Discounting}

In both the BSP and AP models, the initial outputs from the model show forecast expenditure every year from the date of the accounts (December 2009 or December 2010) until 2114. However, for the supplementary table, a single figure representing the present value of accrued-to-date obligations is required. Therefore, future expenditure flows are discounted using a discount rate (see Box 3 ) and summed to give a single figure.

\section{Box 3: The discount rate}

The discount rate $(r)$ is the rate which is used to convert future payments into a 'present value' at a particular date. For example, the present value (PV) at time $(t)$ of a payment $(P)$ payable one year in future $(a t+1)$ is calculated as:

$$
\mathrm{PV}_{t}=\frac{\mathrm{P}_{t+1}}{(1+r)}
$$

In the case of pensions, there is a stream of payments for many years into the future which are discounted to calculate the present value.

For the supplementary table, Eurostat requires that the same discount rate be used in all EU countries and for all government-managed pension schemes including social security pension schemes (Column H) ${ }^{13}$. For the 2010 supplementary table, the rate that Eurostat has asked all EU countries to use is 3 per cent real (or 5 per cent nominal).

\footnotetext{
${ }^{13}$ See 'Pensions in the National Accounts: Compiling a complete picture of UK pensions including unfunded pensions for public sector employees' (Sources and further reading).
} 
Eurostat's approach is similar to the 'social time preference rate' approach used for cost benefit analysis/project appraisal by the UK Government, following guidance in HM Treasury's 'Green Book $^{14}$. The Green Book prescribes a standard discount rate of 3.5 per cent (real) but says that a lower rate may be appropriate for long term usage. The approach is also similar to the method adopted by HM Treasury for setting contribution rates in public service pension scheme valuations using the Superannuation Contribution Accruing for Past Experience (SCAPE) rate. The SCAPE rate is a stable discount rate. It was revised in the March 2011 Budget from 3.5 per cent (real, in excess of RPI), where it had been fixed since the late 1990s, to 3 per cent (real, in excess of CPI).

For the work on Column $\mathrm{H}$ of the supplementary table, a 5 per cent nominal discount rate has been used. This has been adjusted to allow for the effect of moving from financial to calendar years in the spreadsheets used for discounting (see Appendix 1).

\section{Conclusion}

ONS is working to produce the first official estimate of the total obligations of UK pension schemes, including state pensions. The obligations to pay future state pensions are entitlements from the point of view of households and liabilities from the point of view of government. They are properly defined as 'contingent pension obligations' rather than debt in the Maastricht sense.

ONS has commissioned DWP to produce estimates of state pensions for the 2010 experimental supplementary table on pensions, which is part of new international requirements for the National Accounts. Pension obligations in the supplementary table are estimated on an accrued-to-date basis, showing amounts due for service to date, excluding rights which will be built up in the future.

The work by DWP has involved adapting existing models used for long term projections of expenditure on the basic and additional state pensions, and overcoming several challenges in the process. ONS and GAD have quality assured the results, and GAD has recommended a number of improvements. Some of these are being implemented for the 2010 supplementary table and others will be considered as part of work for future supplementary tables.

\footnotetext{
${ }^{14}$ See HM Treasury (2003), Sources and further reading.
} 


\section{Sources and further reading}

Department for Work and Pensions (2011): 'DWP Long Term Basic State Pension Modelling'. Available on request.

Department for Work and Pensions (2011): 'DWP Earnings Factor Modelling: Turning earnings distributions into earnings factors'. Available on request.

Eurostat/European Central Bank (2011): Technical compilation guide on pensions data in National Accounts, second draft for the Eurostat/ECB Contact Group on the statistical measurement of the assets and liabilities of pension schemes in general government. Available on request.

HM Treasury (2003): The Green Book: Appraisal and Evaluation in Central Government. Available at: www.hm-treasury.gov.uk/data_greenbook_index.htm

HM Treasury (2011): Whole of Government Accounts: Unaudited Summary Report for the year ended 31 March 2010, published July 2011. Available at www.hm-

treasury.gov.uk/psr_government_accounts.htm

Hobbs, D. (2010a), Office for National Statistics: Wider measures of public sector debt: A broader approach to the public sector balance sheet. Available at www.ons.gov.uk/ons/rel/psa/widermeasures-of-public-sector-debt/july-2010/index.html

Hobbs, D. (2010b), Office for National Statistics: Wider measures of public sector debt: an update. Available at www.ons.gov.uk/ons/rel/psa/wider-measures-of-public-sector-debt/september-2010-update-/index.html

Levy, S. (2011): 'Pensions in the National Accounts: Compiling a complete picture of UK pensions including unfunded pensions for public sector employees', Office for National Statistics. Available at: www.ons.gov.uk/ons/rel/pensions/pensions-in-the-national-accounts/compiling-a-completepicture-of-uk-pensions-including-unfunded-pensions-for-public-sector-employees--methodologyarticle-2011-/index.html

Office for Budget Responsibility (2011): Fiscal sustainability report, July 2011. Available at http://budgetresponsibility.independent.gov.uk

Office for National Statistics Pension Trends, available at www.ons.gov.uk/ons/about-ons/ourstatistics/publications/pension-trends/index.html

System of National Accounts 2008 (SNA2008), published jointly by the European Commission, the International Monetary Fund, the Organisation for Economic Co-operation and Development, the United Nations and the World Bank. New York, 2009. 


\section{Appendix 1: Adjustment to discounting approach}

This appendix is an extract from the quality assurance report by the Government Actuary's Department (GAD) which discusses a recommended adjustment to the discounting approach to allow for changes from financial year to calendar year. The outcome is also shown.

\section{Extract from the GAD quality assurance report}

"DWP provided some figures for total expenditure on state pensions over the years 2006-07 to 2010-11, which provided no evidence that the payments were spread unevenly over the year. In particular, the proportion of payments made by the end of December each year was very close to $75.0 \%$. Thus it seemed entirely reasonable to assume that $1 / 4$ of the payments from the $2010-11$ year should be included in the present value calculation as at $31^{\text {st }}$ December 2010 (and similarly, that $1 / 4$ of the payments from the 2009-10 year should be included in the present value calculation as at $31^{\text {st }}$ December 2009).

"The discounting of projected amounts of expenditure in each (financial) year to give present values was done in the workbook "PV_ONS_201110921_UK.xls". This was easy to understand. To produce the present value as at end December 2010, it summed:

- $\quad 1 / 4$ of the year's expenditure in the FY 2010-11 (discussed in paragraph 23) with no discounting

- expenditure in the FY $2011-12$ discounted by $5 \%$, that is, divided by 1.05 , where $5 \%$ is the discount rate mandated under ESA 2010

- expenditure in the FY 2012-13 discounted by dividing by a factor of $1.05^{2}$

- expenditure in the FY 2013-14 discounted by dividing by a factor of $1.05^{3}$

- and so on.

"Take as an example, the figures for 2011-12. These payments fall on average mid-way through the financial year, that is at the end of September (assuming that payments are more or less level over the year). Therefore, to produce a present value as at 31st December 2010, the payment for 2011-12 needs to be discounted by a factor of $1.05^{0.75}$, that is, for the 9 month period from end September back to $31^{\text {st }}$ December. This issue will apply for each subsequent year as well - for example, the figure for $2012-13$ should be discounted by $1.05^{1.75}$ rather than $1.05^{2}$. Thus the totals as calculated will be $1.05^{0.25}$ too small (about $11 / 4 \%$ )".

\section{$\underline{\text { Outcome }}$}

As a result of the advice from GAD, DWP has adjusted its approach to producing present value figures for the National Accounts supplementary table on pensions. For example, the present value at 31 December 2010 is the sum of:

- $1 / 4$ of the year's expenditure in the FY 2010-11 with no discounting

- expenditure in the FY 2011-12 discounted by dividing by a factor of $1.05^{0.75}$

- expenditure in the FY 2012-13 discounted by dividing by a factor of $1.05^{1.75}$

- expenditure in the FY 2013-14 discounted by dividing by a factor of $1.05^{2.75}$

- and so on. 